\title{
Profiling indigenous lead-reducing bacteria from Tempe Lake, South Sulawesi, Indonesia as bioremediation agents
}

\author{
AHMAD YANI ${ }^{1,2}$, MOHAMAD AMIN ${ }^{1,3}$, FATCHUR ROHMAN $^{1, \nu}$, ENDANG SUARSINI ${ }^{1}$, WIRA EKA PUTRA ${ }^{1,3}$ \\ ${ }^{1}$ Department of Biology, Faculty of Mathematics and Natural Sciences, Universitas Negeri Malang. Jl. Semarang No. 5, Malang 65145, East Java, \\ Indonesia. Tel./fax.: +62-341-552180,`email: fatchur.rohman.fmipa@um.ac.id \\ ${ }^{2}$ Department of Biology Education, Faculty of Teacher Training and Education, Universitas Puangrimaggalatung. J1. Sultan Hasannudin, Wajo 90915, \\ South Sulawesi, Indonesia. \\ ${ }^{3}$ Department of Biotechnology, Faculty of Mathematics and Natural Sciences, Universitas Negeri Malang. Jl. Semarang No. 5, Mala ng 65145, East Java, \\ Indonesia
}

Manuscript received: 10 July 2020. Revision accepted: 24 September 2020.

\begin{abstract}
Yani A, Amin M, Rohman F, Suarsini E, Putra WE. 2020. Profiling indigenous lead-reducing bacteria from Tempe Lake, South Sulawesi, Indonesia as bioremediation agents. Biodiversitas 21: 4778-4786. The pollution of heavy metals by anthropogenic activities in freshwater, especially in lakes, reduces the quality and endangers the existence of aquatic flora and fauna. This happens in Lake Tempe, which is located, in South Sulawesi, Indonesia. The study aimed to evaluate the content of heavy metals, isolation, and identify a lead reduction of indigenous bacteria as candidates for bioremediation agents. It began by examining the level of cadmium $(\mathrm{Cd})$, copper $(\mathrm{Cu})$, and lead $(\mathrm{Pb})$ in seven sampling sites of Tempe Lake. Furthermore, propagation and isolation, morphological observation, laboratory-scale reduction tests, and species identification of potential bacteria reduction $\mathrm{Pb}$ were performed by using $16 \mathrm{~s}$ rDNA. The reduction test to $\mathrm{Pb}$ was measured using Atomic Absorption Spectrometry (AAS), and the research data were analyzed using One-Way ANOVA with the Duncan advanced method. The results showed that the $\mathrm{Cd}, \mathrm{Cu}$, and $\mathrm{Pb}$ content of the seven sampling points exceeded the water quality standard Following the Indonesian Government Regulation (IGR) and WHO standards. Pb has the highest concentration among the other heavy metals in the water sample reaching $0.40 \mathrm{mg} / \mathrm{L}$. Four bacterial isolates could grow on $\mathrm{Pb}$-enriched media (isolates A, B, C, and D). The Bacillus form was found in two different species bacteria (isolate A and D), while the cocci shape was found in two other species (isolate $\mathrm{B}$ and $\mathrm{C}$ ). Those all Gram-negative bacteria were observed to be a reduction to $\mathrm{Pb}$ exposure within a bacterial medium. Interestingly, these indigenous bacteria could decrease $\mathrm{Pb}$ concentration ranging from 7.45 to $3.48 \mathrm{ppm}$ for seven days. Furthermore, the sequencing data showed that the indigenous bacteria (isolate D) had a $99.90 \%$ similarity to the Comamonas testosteroni strain S-2 constructed using Neighbor-joining phylogenetic analysis. Therefore, the indigenous bacteria $C$. testosteroni strain $\mathrm{S}-2$ from Tempe lake may be proposed as a bioremediation agent to reduce $\mathrm{Pb}$ the water contaminants.
\end{abstract}

Keywords: Bioremediation, Comamonas testosteroni, indigenous bacteria, Lake Tempe, lead-reduction

\section{INTRODUCTION}

Contamination in the natural environment through anthropogenic activities releases many toxic elements and compounds in quantities that exceed the carrying capacity (Jan et al. 2015; Anyanwu et al. 2018; Sowmya and Mohamed 2017). The toxic chemicals released tend to be accumulated in the living organism, the abiotic factor, and the ecosystem chain (Ali et al. 2019). Furthermore, the contamination of metalloid compounds in the water affects the reduction of the quality (Gafur et al. 2018), changes the balance of ecosystems, damages the aquatic organism (Igiri et al. 2018), and destroys ecological landscapes as well as decreases biodiversity (Bello et al. 2018). Heavy metal pollution from anthropogenic activities in freshwater, especially in lakes, has increased in several countries such as Taihu, China (Li et al. 2018), Poyang in China (Jiang et al. 2019), and Habbaniyah Al-Anbar in Iraq (Khazaal et al. 2019).

Similar phenomena were observed in Indonesia, especially in Tempe Lake, allegedly contaminated by heavy metals (Pance et al. 2014). Communities living on the coast usually depend on Lake Tempe for their livelihoods, such as fishing, farming, and various daily activities. (Yani et al. 2019). Sanitation and household and municipal waste with the results of day-to-day operations, tend to be drained into rivers and eventually flow into the lake (Haerunnisa et al. 2015). The water quality test results of the Tempe Lake reported by the Wajo District Regional Environment Agency indicated that some physicochemical parameters had exceeded the maximum threshold. In contrast, heavy metals exceeded standards for cadmium, copper, and zinc (Pance et al. 2014). Besides, the booming Eichhornia crassipes population in Lake Tempe is a biological indicator that heavy metals are contaminants of the aquatic environment. Primarily, lead is one of the metalloid compounds that often pollute the environment, especially waters.

Lead is a type of heavy metal primarily obtained from aquatic environments (Carolin et al. 2017; Cheyne et al. 2017), becoming one of the most common naturally occurring substances on earth (Jan et al. 2015). It is a mutagenic and teratogenic metal group that exerts toxicological effects on the kidney, bone marrow, digestive, cardiovascular, reproductive, nervous, and immune systems of the human body (Chen et al. 2015; Pan 
et al. 2017). The toxicological effects of heavy metals originate from the food chain cycle, one of which is present in water. $\mathrm{Pb}$ has contaminated the water environment due to industrial operations, agriculture, and various community activities that directly eliminate wastes (Kang et al. 2015). It is also produced through anthropogenic and natural processes such as soil erosion, volcanic emissions, and mineral lead mobilization (Sharma and Shukla 2021).

An attempt to manage contaminated water environments may use biological agents or bioremediation by microorganisms such as bacteria (Gohil et al. 2019). Bioremediation provides a safer way to get rid of environmental contaminants, such as lead pollution. According to Igiri et al. (2018), bioremediation technology is more productive and affordable than physical and chemical. Microorganisms have used several methods to eliminate the lead found in the environment. Bacteria use the material in their habitat as a source of nutrients through metabolic processes and survive in contaminated areas (Sowmya and Mohamed 2017).

Some studies reported that bacteria such as Aneurinibacillus aneurinilyticus isolated from ground water in Burdwan, India, reduce contamination levels in water bodies (Dey et al. 2016). Comamonas testosteroni $\$ 44$ bacteria reducing selenite is isolated from soil contaminated with metals (Zheng et al. 2014). Proteus mirabilis, Bacillus safensis, Alcaligenes faecalis, and Pseudomonas aeruginosa bacteria are tolerant to heavy metals $\mathrm{Cr}, \mathrm{Cd}$, and $\mathrm{Ni}$, are isolated from Mine Tailings Rustenburg, South Africa (Junior et al. 2017). Klebsiella pneumoniae and Mangrovibacter yixingensis bacteria were able to reduce the heavy metal chromium $(\mathrm{Cr})$ isolated from Indian tannery waste Tamil Nadu (Sanjay et al. 2018). However, some studies have successfully detected bacteria resistant to heavy metals. Little effort has been provided to control lead by isolating the bacteria from the area of contamination. The bacteria used as bioremediation agents were mostly cultured (commercial), even when Tempe Lake is confirmed to have been polluted with heavy metals lead (Haerunnisa et al. 2015; Pance et al. 2014). According to Risna et al. (2020), the concentration levels have exceeded the threshold, and this is evident in the histological test of Bungo Fish (Glossogobius sp.) containing $\mathrm{Pb}$ metal. This allows the isolation of indigenized bacteria from the contaminated area. Besides, no study has yet discovered that Tempe Lake contains isolated lead-reducing bacteria, suggesting heavy metal pollution. The presence of microbes in water plays a potential role as biodegradable agents in the metabolism of these organic and inorganic compounds (Igiri et al. 2018).

Due to the environmental problems of Lake Tempe, mostly the $\mathrm{Pb}$ contaminated water, a concrete solution is needed to overcome these problems. Furthermore, to maintain the water quality in its natural state, it is necessary to control pollution wisely. An alternative solution to overcome these problems is to use bacteria as bioremediation agents. However, it is required to start measuring the metal content and isolating bacteria from the polluted area. Therefore, this study begins by measuring the concentration of heavy metal $(\mathrm{Pb}, \mathrm{Cd}$, and $\mathrm{Cu})$ in Lake
Tempe's waters, isolating bacteria that reduce the lead metal content and screened potential bacteria to lead reduction. The isolate with the highest reduction in the lead is characterized for further studies and the indigenous species is determined based on the sequence of the $16 \mathrm{~S}$ rDNA gene.

\section{MATERIALS AND METHODS}

\section{Study area}

Lake Tempe is one of Indonesia's critical lakes and based on the analysis of the water quality index, it is currently polluted. It is characterized by several physicochemical parameters that have exceeded the threshold value (turbidity, TSS, BOD, nitrate, and phosphate) (Yani et al. 2019) and experiencing eutrophication (Aisyah and Nomosatryo 2016). The geographical location is located between $3^{\circ} 39^{\prime}-4^{\circ} 16$, latitude and $119^{\circ} 53^{\prime}-120^{\circ} 27$ 'East Longitude. The lake area at Wajo District, South Sulawesi, Indonesia varies between 9,425 hectares and a tropical monsoon climate with a depth of 3 to 5 meters in the rainy season and 0.5 to 2 meters in the dry season (Haerunnisa et al. 2015). It is a flood plain type lake with a large river basin as the inlet and another one as the outlet.

The Tempe water sampling location was determined using the sample collection method at seven points based on land use characteristics and community activities. The sampling point: (1) $120^{\circ} 1$ '17,547'E, 4'8'42,427'S; (2) $120^{\circ} 1$ '45,377'E, 48'42,427’'S; (3) 119 $58^{\circ} 52,926^{\prime \prime} \mathrm{E}$, 4०7'31,511'S; (4) 119॰58'39,541'"E, 47'31,511'S; (5)

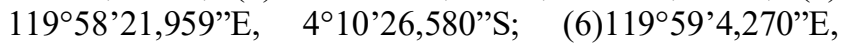
4³'59,246”S; (7) 120¹'5,686”E, 45”59,110”S (Figure $1)$. These characteristics include land use for agriculture, fishing, urban sewerage, and densely populated areas (community activities). However, considering ease of access, cost, and time, sample points are identified to represent the quality of the seawater heavy metal measurements conducted during the transition from the rainy to the dry season. Meanwhile, the sampling point was chosen to isolate native bacteria that degrade heavy metal lead $(\mathrm{Pb})$ based on the highest content.

\section{Procedures}

Heavy metals characterization of water samples

The design was used to test the heavy metals $(\mathrm{Cd}, \mathrm{Cu}$, and $\mathrm{Pb}$ ) levels of Lake Tempe by taking water samples at a predetermined segment or point. The collection and testing were conducted twice with an interval of one day on the ground that its presence represents the lake's metal content. Furthermore, the seawater sampling at each point was conducted using a random sampling method (taking a moment). Water samples were taken at 09.00-10.00 a.m using a simple tool in the form of a long-handled plastic shovel following Indonesia National Standard 6989.592008 about the method of wastewater sampling. Water samples were taken at a depth of 2-5 meters from the water surface and poured in a 1-liter plastic polyethylene bottles at each sampling point. Additionally, the water sample was directly taken to the environmental laboratory of the 
province of South Sulawesi for analysis. The concentration of heavy metal $(\mathrm{Cd}, \mathrm{Cu}$, and $\mathrm{Pb})$ contents as measured using Atomic Absorption Spectrometry (AAS) (PerkinElmer 5100 PC). Determination of the standard heavy metal $(\mathrm{Cd}, \mathrm{Cu}$, and $\mathrm{Pb})$ values water sample is based on the usual water quality Indonesian Government Regulation (IGR) and the World Health Organization (WHO).

\section{Propagation and isolation of lead reduction bacteria}

Standard Bacteriological Sampling Protocols were duly followed when collecting water samples, and the process of isolating indigenous bacteria was performed in the microbiological laboratory, Universitas Negeri Malang, Indonesian. The procedures involved are as follows: a) 50 $\mathrm{ml}$ of water sample was mixed in $450 \mathrm{ml}$ of Luria Bertani (L.B.) medium, which was incubated for 24 hours; b) the mixture was then agitating speed of $120 \mathrm{rpm}$ for 3-4 days. The bacteria isolation was performed according to the following method: a) $10 \mathrm{ml}$ of the amplified and the propagated samples were dissolved in $90 \mathrm{ml}$ of a peptone solution and mixed thoroughly on a magnetic stirrer at 150 rpm 2-3 minutes. b) $1 \mathrm{ml}$ of a $90 \mathrm{ml}$ solution of peptone solution $+10 \mathrm{ml}$ of sample was suspended in a test tube containing $9 \mathrm{ml}$ of $0.1 \%$ peptone water with a serial dilution standard (10-1 to $10-8)$, c) at a $10-5$ to $10-8$ dilution to $0.1 \mathrm{ml}$ of the solution was suspended in enriched $0.5 \% \mathrm{~Pb}$ Nutrient Agar (N.A.) plate and then incubated at $37^{\circ} \mathrm{C}$ for 24 hours. Also, the selected colonies were chosen for morphological analysis, and we're further inoculated on oblique N.A. medium and incubated on slant medium for 24 hours at $37^{\circ} \mathrm{C}$ for isolation.

\section{Determination of lead-reduction bacteria}

The bacteria were grown on the N.A. medium and incubated at $37^{\circ} \mathrm{C}$ for 24 hours. The reduction in the lead was then determined as follows: inoculation of 2 to 3 bacteria into the Nutrient Broth (NB.) medium $50 \mathrm{ml}$ for 24 hours at $37^{\circ} \mathrm{C}$, measuring the volume and descent cells growing with $\mathrm{Mc}$ Farland, adding $0.5 \% \mathrm{~Pb}\left(\mathrm{NO}_{3}\right)_{2}$ to the N.B. medium containing bacteria and $0.5 \% \mathrm{~Pb}\left(\mathrm{NO}_{3}\right)_{2}$, shaking at a temperature of $100 \mathrm{rpm} .37^{\circ} \mathrm{C}$ for seven days (Batta et al. 2013). The $\mathrm{Pb}$ content was measured daily using ASS analyzed. Also, the determination of potential $\mathrm{Pb}\left(\mathrm{NO}_{3}\right)_{2}$ bacteria was performed by analyzing the decreased level for seven days. The percentage (\%) removal of $\mathrm{Pb}$ was determined using the equation: \% Removal of $\mathrm{Pb}=\mathrm{Pb}$ (initial) $-\mathrm{Pb}$ (final) $/ \mathrm{Pb}$ (final) $\times 100$ (Talukdar et al. 2020). Furthermore, it was used to determine the bacterial isolate with the most potential to reduce the $\mathrm{Pb}$ metal content. The data were analyzed by One-Way ANOVA $(\mathrm{p}<0.05)$ and the Duncan advanced test (Pambudiono et al. 2016; Sa' diyah et al. 2017). Meanwhile, a species identification procedure will be conducted for the bacteria that have been selected.

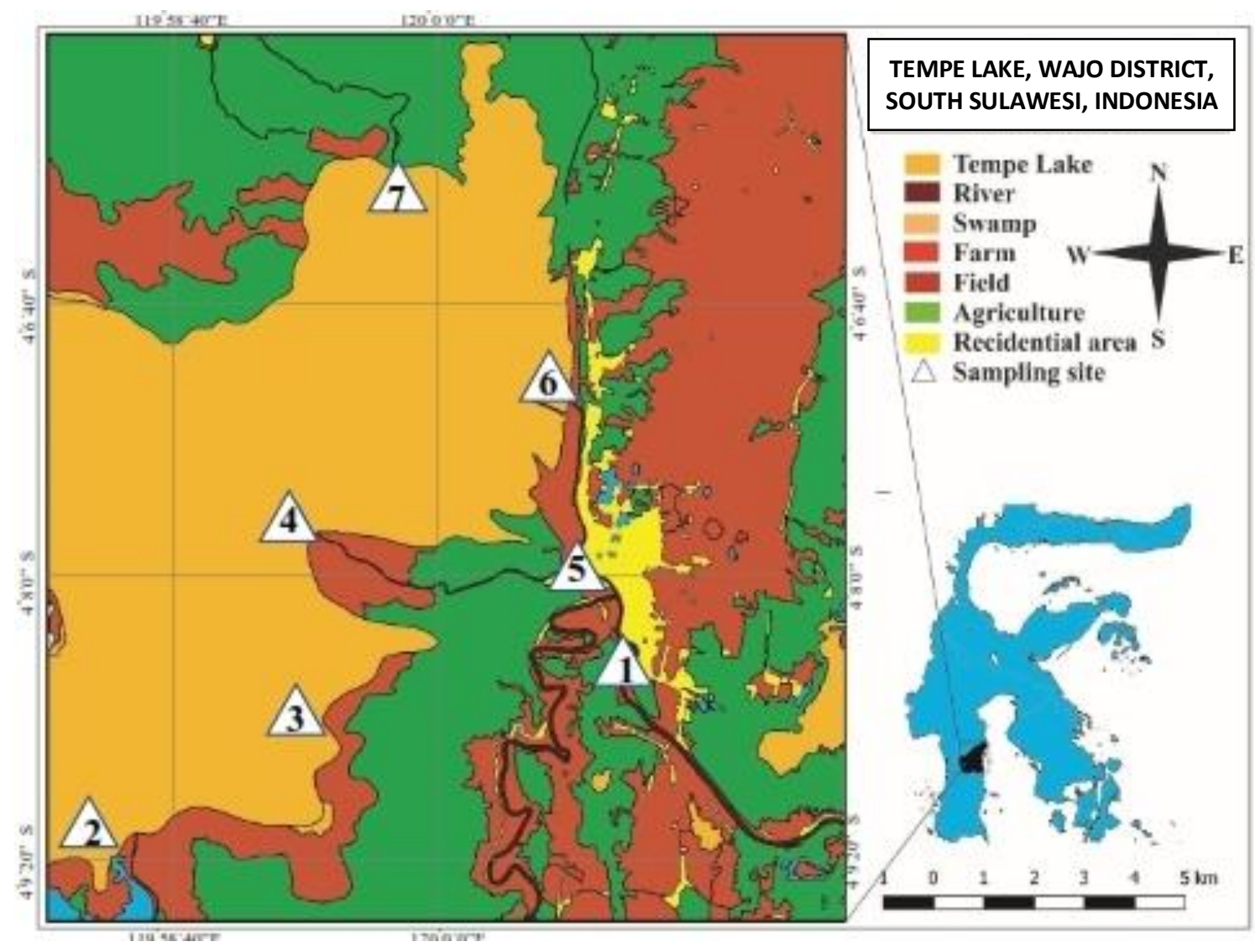

Figure 1. Sampling site of Tempe Lake, Wajo District, South Sulawesi, Indonesia 
Morphological and molecular identification of isolate potential

Bacterial isolates that have grown to the inclined medium after the insulation phase can be classified morphologically. Gram staining morphological Identification was made to determine the type, cell shape, and cell size based on Bergey's Manual of Systematic Bacteriology (Krieg and Holt 1984). Additionally, the Identification of bacterial species was only conducted on bacteria with the highest ability to reduce metals after a lab-scale reduction test. However, indigenous bacteria, which have the highest potential to reduce $\mathrm{Pb}\left(\mathrm{NO}_{3}\right)_{2}$, were molecularly identified by $16 \mathrm{~s}$ rDNA sequences.

Genomic DNA was extracted with PrestoTM Mini gDNA Bacteria KIT (Geneaid) following the manufacturer's instructions. The results of DNA extraction were performed using the universal primers $16 \mathrm{~s}$ rDNA, 27F (5'-AGAGTTGATCMTGGCTCAG-3'), and 1429R (5'TACGGYTACCTTGTTACGACTT-3') (Irawati et al. 2019; Sanjay et al. 2018). The PCR process using a total volume mixture of $50 \mu \mathrm{L}$ PCR reaction which consisted of $25 \mu \mathrm{L}$ PCR Mix (Green Gotaq Promega), $2 \mu \mathrm{L}$ primer forward (P1) and $2 \mu \mathrm{L}$ reverse (P2), $19 \mu \mathrm{L}$ ddH2O, and 2 $\mu \mathrm{L}$ DNA templates. The temperature profile used for PCR amplification was as follows: the initial denaturation at $95^{\circ} \mathrm{C}$ for $3 \mathrm{~min}$ followed by 35 cycles at $95{ }^{\circ} \mathrm{C}$ for $30 \mathrm{~s}$; annealing at $55^{\circ} \mathrm{C}$ for $1 \mathrm{~min}$ and extension at $72{ }^{\circ} \mathrm{C}$ for 1 min; final extension at $72{ }^{\circ} \mathrm{C}$ for $10 \mathrm{~min}$ (Batta et al. 2013; Garcha et al. 2016). Amplicon 16s rDNA and marker 10.000 kb ladder DNA (Promega, City, USA) were spotted on a $1 \%$ agarose gel with a dye of $1 \mu \mathrm{L}$ ethidium bromide and then visualized using a UV-Transilluminator (Sanjay et al. 2018).

Amplicon 16s rDNA was purified and sequenced at Genetika Science, Indonesia. Furthermore, each 16S rDNA sequence was aligned with the reference from GenBank of the NCBI to construct a phylogenetic tree based on the Neighbor-Joining algorithm with bootstrap 1000 replication using MEGA software version 6.0 (Tamura et al. 2013). The identified potential lead-reducing bacteria species were stored in the laboratory as culture stock.

\section{RESULTS AND DISCUSSION}

\section{Water heavy metals pollution characterization}

Three types of heavy metals $(\mathrm{Cd}, \mathrm{Cu}$, and $\mathrm{Pb})$ were measured in the waters of Tempe Lake. The measured values outperformed the water quality standards according to IGR, while based on the WHO water quality standards, only heavy metals $\mathrm{Cu}$ met the criteria.

Based on Table 1, the highest heavy metal concentration was lead. The levels at seven sampling sites exceeded water quality standards from IGR and WHO
Standard. Heavy metals pollute water through natural and anthropogenic sources. Besides, one of the biological indicators showing that heavy metals contamination in Tempe Lake is the increasing population of E. crassipes (Figure 2).

\section{Propagation and isolation of cadmium reduction bacteria}

The propagation results of the Tempe lake water sample added with the L.B. medium showed that there was bacterial activity. Based on visual inhibition, it is characterized by a change in color of the medium, which is more concentrated after 24 hours at $37^{\circ} \mathrm{C}$. Furthermore, the isolation results reported bacterial colonies that can grow on L.B. medium enriched with $\mathrm{Pb}(0.5 \%)$ after 24 hours of incubation. This is evidenced by the growth of bacterial colonies on the N.A. media after the retail process. According to Marzan et al. (2017), heavy metal resistant bacteria $\mathrm{Pb}$ may survive on L.B. medium enriched with $300 \mu \mathrm{g} / \mathrm{mL}$ heavy metal $\mathrm{Pb}$. Four bacteria were isolated after examination and visual observation and were coded A, B, C, and D to identify their bacterial morphology as well as their ability to reduce $\mathrm{Pb}$ at the laboratory scale.

\section{Morphological Identification of isolate}

Four isolated growing bacteria on the $\mathrm{Pb}$-enriched medium obtained the indigenous bacteria. The results of Gram staining showed that the four isolated bacteria were Gram-negative, and the cell forms were A and D basil, as well as $\mathrm{B}$ and $\mathrm{C}$ coccus, growing at $10-45^{\circ} \mathrm{C}$, and optimal at $37^{\circ} \mathrm{C}$.

\section{Lead reduction test}

The results of isolated bacteria were reduced to $\mathrm{Pb}$ and became candidates for bioremediation agents. The leadreduction test was characterized by decreasing the concentration with the initial at $7.475 \mathrm{ppm}$ based on the lead medium enrichment. The results from the Tempe Lake are shown in Figure 3. This figure showed that the four isolated native bacteria may reduce lead levels to 3.488 ppm after been were tested for seven days. From the statistical analysis, the whole isolate showed a significant difference in the reduction of $\mathrm{Pb}$ content in the water samples. There was a statistically significant difference between groups as determined by One Way ANOVA ( $\mathrm{F}=$ 10.362, $\mathrm{P}=0.023$ ). During the seven days, the $\mathrm{Pb}$ content decreased from 6,908 to $3,854 \mathrm{mg} / \mathrm{L}$ (treatment with isolate A), 7,333 to $4,727 \mathrm{mg} / \mathrm{L}$ (treatment with isolate B), 6,690 to $3,809 \mathrm{mg} / \mathrm{L}$ (treatment with isolate $\mathrm{C}$ ), 6,380 to 3,488 $\mathrm{mg} / \mathrm{L}$ (isolate $\mathrm{D}$ treatment). Of the four bacteria tested, there were differences in the lead-reducing ability of each isolate based on Duncan's continuous testing (Table 2).

Table 1. Heavy metals concentration in the waters of Lake Tempe, South Sulawesi, Indonesia

\begin{tabular}{|c|c|c|c|c|c|c|c|c|c|c|}
\hline \multirow{2}{*}{ Heavy metals } & \multirow{2}{*}{ Unit } & \multicolumn{7}{|c|}{ Sampling point } & \multirow{2}{*}{ IGR standards } & \multirow{2}{*}{ WHO standards } \\
\hline & & 1 & 2 & 3 & 4 & 5 & 6 & 7 & & \\
\hline Cadmium & $\mathrm{mg} / \mathrm{L}$ & 0.12 & 0.12 & 0.13 & 0.14 & 0.02 & 0.02 & 0.01 & 0.01 & 0.003 \\
\hline Copper & $\mathrm{mg} / \mathrm{L}$ & 0.03 & 0.04 & 0.04 & 0.05 & 0.04 & 0.04 & 0.03 & 0.02 & 2.000 \\
\hline Lead & $\mathrm{mg} / \mathrm{L}$ & 0.25 & 0.29 & 0.30 & 0.34 & 0.35 & 0.40 & 0.40 & 0.03 & 0.010 \\
\hline
\end{tabular}


Table 2. The results of the Duncan Advanced Test analysis

\begin{tabular}{lccccccc}
\hline \multirow{2}{*}{ Isolate code } & \multicolumn{7}{c}{ Concentration } \\
\cline { 2 - 8 } & $\mathbf{1}$ & $\mathbf{2}$ & $\mathbf{3}$ & $\mathbf{4}$ & $\mathbf{5}$ & $\mathbf{6}$ & $\mathbf{7}(\mathbf{d a y s})$ \\
\hline $\mathrm{A}$ & $6.908^{\mathrm{de}}$ & $6.678^{\mathrm{ab}}$ & $6.311^{\mathrm{ab}}$ & $5.817^{\mathrm{bc}}$ & $5.117^{\mathrm{ef}}$ & $4.578^{\mathrm{cd}}$ & $3.854^{\mathrm{f}}$ \\
$\mathrm{B}$ & $7.333^{\mathrm{a}}$ & $7.218^{\mathrm{ab}}$ & $6.828^{\mathrm{cd}}$ & $6.472^{\mathrm{c}}$ & $5.829^{\mathrm{f}}$ & $5.404^{\mathrm{de}}$ & $4.727^{\mathrm{f}}$ \\
$\mathrm{C}$ & $6.690^{\mathrm{f}}$ & $6.495^{\mathrm{a}}$ & $6.035^{\mathrm{b}}$ & $5.519^{\mathrm{bc}}$ & $4.910^{\mathrm{ef}}$ & $4.371^{\mathrm{cd}}$ & $3.809^{\mathrm{de}}$ \\
$\mathrm{D}$ & $6.380^{\mathrm{f}}$ & $6.024^{\mathrm{a}}$ & $5.657^{\mathrm{ab}}$ & $5.163^{\mathrm{bc}}$ & $4.612^{\mathrm{cd}}$ & $4.119^{\mathrm{bc}}$ & $3.488^{\mathrm{de}}$ \\
\hline
\end{tabular}

Note: The different notations showed significant differences among the group $(\mathrm{p}<0.05)$
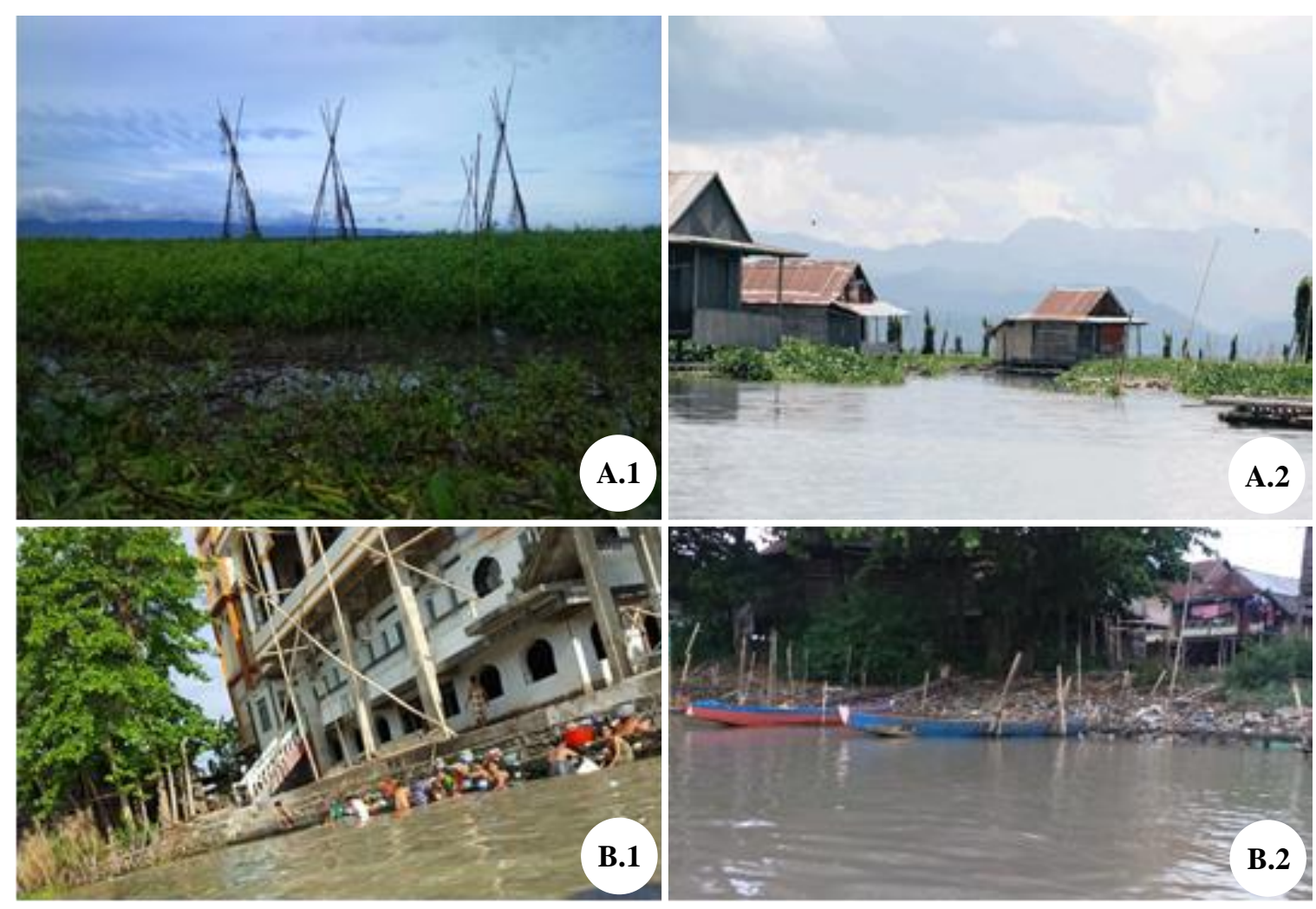

Figure 2.A. Eichhornia crassipes bloom in Tempe lake; B. Community activities in coastal lakes

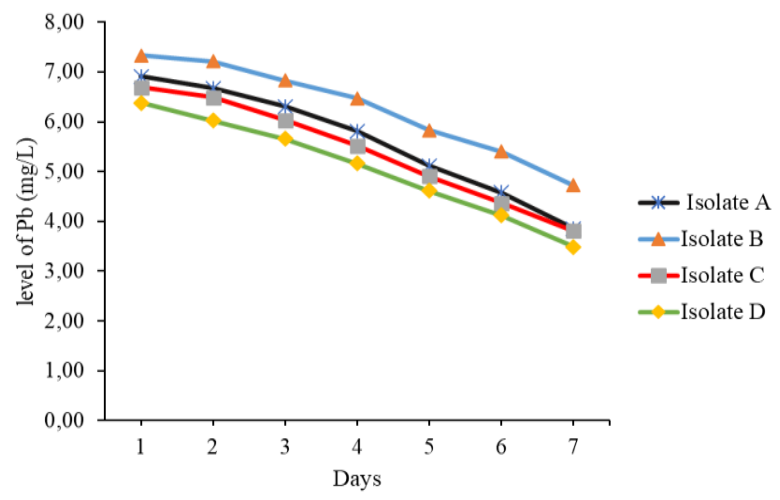

Figure 3. Levels of heavy metal $\mathrm{Pb}$ in the test of isolates ability to reduce $\mathrm{Pb}$ for seven days

Table 2 showed that the isolate has different abilities to reduce the heavy metal $\mathrm{Pb}$ content, which is known from the presence of sample groups covering different subgroups (notations). By isolating $\mathrm{A}$, there was a decrease in the strongest $\mathrm{Pb}$ metal on day 7 , which was not significantly different from day 5. However, it was significantly different from the other days. Isolate $\mathrm{B}$ showed that the most significant reduction of heavy metal $\mathrm{Pb}$ occurred on day seven but was not significantly different from day 5 .

Furthermore, days 7 and 5 were significantly different from the others. In isolate $\mathrm{C}$, the most significant reduction in $\mathrm{Pb}$ heavy metal levels occurred on day one but was not significantly different from day 5 . However, the decrease in metal content on day 1 was significantly different from the other days. Isolate D showed the most significant decrease in $\mathrm{Pb}$ levels on the first day and was essentially independent on the other days. Further test results showed that isolate $\mathrm{D}$ had the best ability to reduce $\mathrm{Pb}$ and was not significantly different from other treatments except for B. Following the results of the effectiveness of each isolate in reducing $\mathrm{Pb}$ levels of heavy metals, Isolate $\mathrm{D}$ was 
determined to have a percentage with the highest levels of reducing metal levels (Figure 4).

Isolate D had the highest percent degradation efficiency of lead $(53.35 \%)$ compared to others. It is believed that the differences influence the ability of each strain to reduce $\mathrm{Pb}$ in the mechanism and knowledge of each bacterium to detoxify heavy metals.

\section{Identification of species lead-reduction bacteria based on the 16s rRNA gene sequence}

The quantitative extraction of lead-reduction DNA has an absorption ratio of 1.93 . The quality test of their DNA extraction was visualized in the U.V. transilluminator geldock (Figure 5). This case showed that DNA samples from $\mathrm{D}$ isolates had good quality in the sequencing phase.

\section{Sequencing}

The BLAST results of the Pb-reduction indigenous bacteria sequence (isolates D) from the 16s rRNA $1407 \mathrm{bp}$ gene sequence had a similarity of $99.90 \%$ with Comamonas testosteroni (Table 3, Figure 6).
The neighbor-joining tree shows the phylogenetic position of lead tolerant isolated indigenous bacteria, $C$. testosteroni strain S-2, identified based on the 16s rDNA sequences. The numbers at the nodes indicated the level of bootstrap support following the Neighbor-Joining analysis of 1000 replicates. The phylogenetic tree represents only the topology, and accession numbers were given in parenthesis.

Table 3. The similarity of isolate $\mathrm{D}$ with reference isolates based on $16 \mathrm{~S}$ rDNA sequence

\begin{tabular}{lc}
\hline Species & $\begin{array}{c}\% \\
\text { similarity }\end{array}$ \\
\hline Comamonas testosteroni strain H18 & 99.70 \\
Comamonas testosteroni strain LMG & 99.80 \\
Comamonas testosteroni strain QT12 & 99.70 \\
Comamonas testosteroni strain JC3 & 98.50 \\
Comamonas testosteroni strain S-2 & 99.90 \\
Comamonas testosteroni strain SW7 & 99.80 \\
Pseudomonas straminea JCM 2783 & 82.70 \\
Pseudomonas straminea strain CICR-DCPPC16 & 82.80 \\
Enterococcus faecium strain DJ1 & 74.00 \\
\hline
\end{tabular}

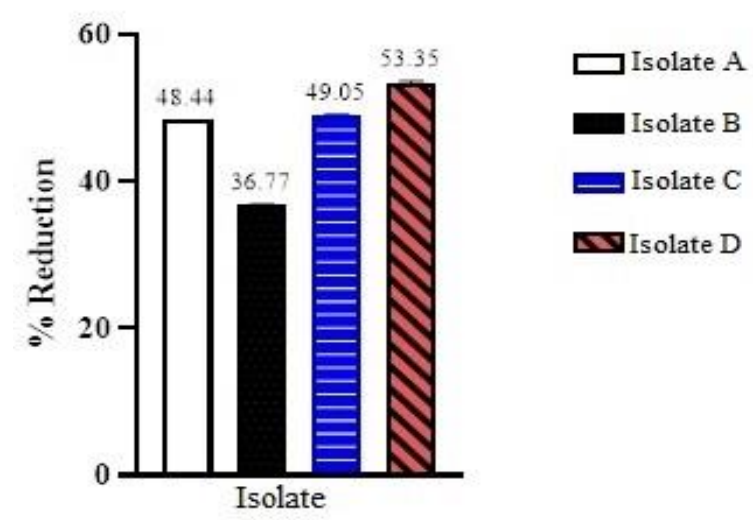

Figure 4. The degradation rate of four isolate bacteria

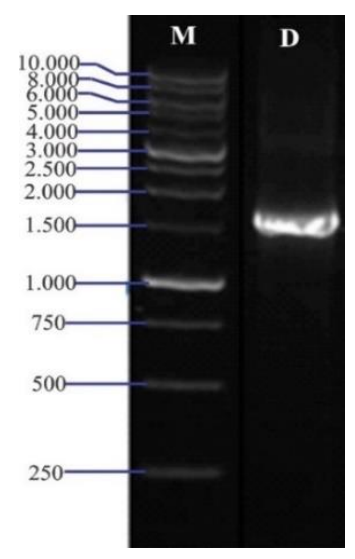

Figure 5. PCR Products of extracted DNA molecules 16s rDNA

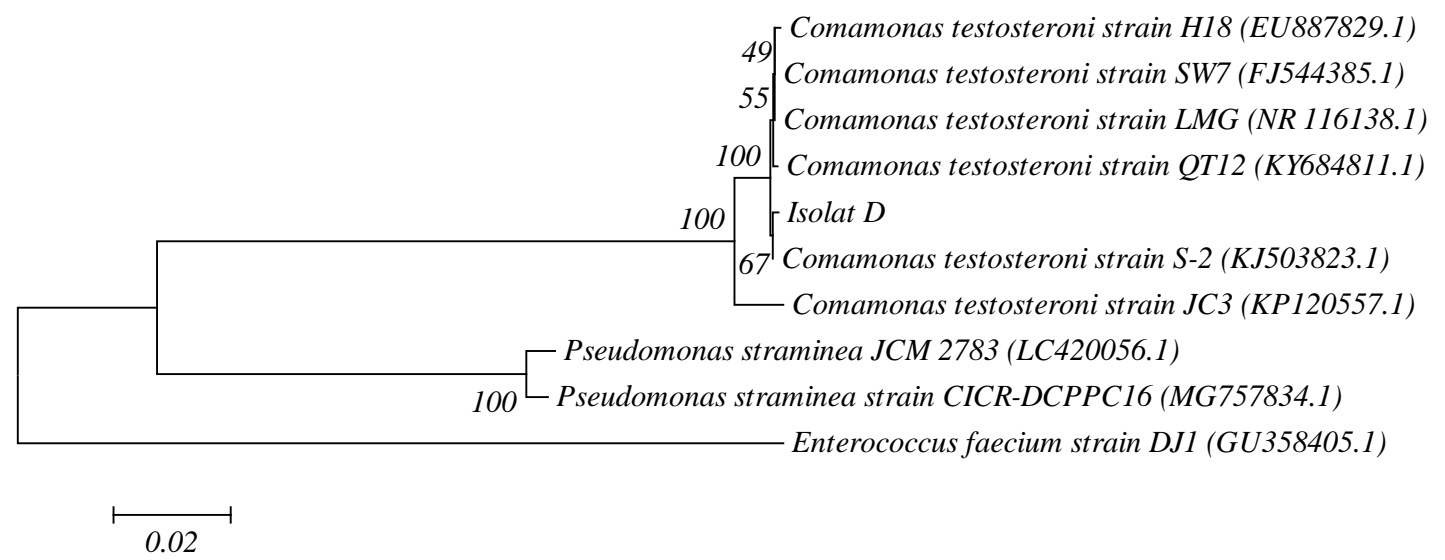

Figure 6. Neighbor-joining phylogenetic tree constructed from 16s rDNA 


\section{Discussion}

The concentration of heavy metals $\mathrm{Cd}$ and $\mathrm{Pb}$ in Tempe Lake has exceeded water quality standards based on Indonesian and WHO water quality standards. $\mathrm{Cu}$ metal is still within tolerance limits based on WHO standards but exceeds IGR standards. These metals pollute water through natural and anthropogenic sources (Anyanwu et al. 2018; Jan et al. 2015). The results of previous studies showed that contaminated lake is caused by household and industrial waste (Li et al. 2018). Similarly, the same has happened in Tempe Lake, where it becomes a secondary terminal for several rivers (Aisyah and Nomosatryo 2016), such as Bila and the Sidenreng watersheds in the north and Batu-Batu in the west (Haerunnisa et al. 2015). Besides, they are affected by various community activities, such as bathing, washing, water transport, agriculture, plantations, fish auctions, and municipal waste (Pance et al. 2014). Uncontrolled water catchment conditions and the use of the lake will have an impact on the ecosystems. These include the water quality decline, the ingress of pollutants into the waters (Rijal et al. 2015; Deepa et al. 2016), sedimentation, and eutrophication (Aisyah and Nomosatryo 2016).

Agricultural, domestic and industrial wastes are the primary sources of heavy metal contaminants. According to Jiang et al. (2019), agricultural waste is a source of heavy metal pollutants. Similarly, Dixit et al. (2015) reported that heavy metals polluted the environment through anthropogenic sources such as air emissions from leadburning fuels, battery wastes, insecticides and herbicides, and natural sources. As stated by Aisyah and Nomosatryo (2016), about $46.60 \%$ of the coastal area of Lake Tempe was used by the community as rice fields. Anthropogenic activities are probably one of the sources of heavy metal pollution in Lake Tempe. Therefore, the conditions of the watershed uncontrolled use of lakes have an impact on the ecosystems, thereby decreasing the water quality.

One of the biological indicators showing that heavy metals pollute Tempe Lake is the increasing E. crassipes. As stated by Parmar et al. (2016), aquatic plants are used as bioindicators for water pollution. E. crassipes can accumulate (reduce) the toxicity of $\mathrm{Ag}, \mathrm{Pb}, \mathrm{Cd}$, and $\mathrm{Cu}$ by using phytoremediation techniques (Kumar et al. 2008; Wang et al. 2011). According to Lu et al. (2004), E. crassipes was used as environmental technology to prevent contamination of $\mathrm{Cd}$ and $\mathrm{Zn}$ in bodies of water. These indicators show that heavy metals contaminate Lake Tempe.

The results of the isolation showed four bacteria resistant to $\mathrm{Pb}\left(\mathrm{NO}_{3}\right)_{2}$., Which grow on media with $\mathrm{Pb}$ $7,475 \mathrm{ppm}$. Furthermore, laboratory-scale tests showed that the four isolates of native bacteria decreased the heavy metal values to 3,488 ppm, and were tested for seven days. Based on the test results from day 1 to day 7, there was a difference in the ability to affect the lead reduction of each isolate. Compared to other strains, isolate D had the highest percentage of $\mathrm{Pb}$ degradation efficiency $(53.35 \%)$. The differences influence the ability of each isolate to reduce $\mathrm{Pb}$ in the mechanism and knowledge of each bacterium to detoxify heavy metals. As suggested by Theiman and
Palladino (2013), bacteria have a different influence on the ecological compatibility of pollutants, depending on the type, the element, and the polluted environmental conditions. According to Dey et al. (2016), when a microbial community remains under selective stress, such as a high concentration of heavy metals, for a very long time, some mechanism must be formed to detoxify it and resolve the growth constraint. As a result, four bacteria isolated from Lake Tempe have been able to thrive on $\mathrm{Pb}$ metal-enriched media and have been able to reduce $\mathrm{Cd}$ metal levels. Researchers announced other results that differences in bacterial cell walls (grams) affect the ability to detoxify contaminants (Mary et al. 2018)

Morphologically, the most potent isolates (isolate D) are Gram-negative, $2 \mu \mathrm{m}$ abundant Bacillus bacteria based on the Bergey Manual (Krieg and Holt 1984). According to Sowmya and Hatha (2017), Gram-negative bacteria bind heavy metals because the cell walls contain lipopolysaccharide, oleic acid, and polychromic acid as binders for heavy metals. Some studies also reported that Gram-negative bacteria are tolerant of heavy metals because their cell walls are a barrier, while the surface structure interacts and detoxifies metal ions (Bennisse et al. 2004; Junior et al. 2017).

Microorganisms have developed mechanisms of resistance and detoxification of metals in contaminated environments (Igiri et al. 2018). This mechanism includes several biochemical and molecular activities (Yang et al. 2015). As reported by Sowmya and Hatha (2017), bacteria prevent the entry of toxic metals into cells after their chemical composition had been changed. A similar finding was reported by Naik and Dubey (2013) that the $\mathrm{Pb}$ resistance mechanism used by bacteria led to an efflux mechanism, extracellular sequestration, biosorption, precipitation, alteration of cell morphology, increasing siderophore production, and intracellular bioaccumulation. Furthermore, they tolerate concentrations of heavy metal toxicity, such as lead, by incorporating intracellular or extracellular absorption surface absorption, ATPasemediated efflux, and conversion to non-toxic forms (Naik et al. 2013). Generally, microbes have different resistance mechanisms against the toxicity of heavy metals by forming intracellular compounds with ions in eukaryotes or reducing the accumulation following the removal of active cations in prokaryotes (Igiri et al. 2018).

The phenotypic characterization of the most $\mathrm{Pb}$ resistant bacteria showed compatibility with the genus Comamonas based on Bergey's Manual of Systematic Bacteria (Krieg and Holt 1984). This is consistent with the results obtained from molecular Identification. Based on 16s rDNA sequences, C. testosteroni species isolated had 99\% similarity. This specie is a Gram-negative bacteria with aerobic properties, which is generally located in various habitats such as activated sludge, swamps, lakes, and seas, plant as well as animal tissues (Black et al. 2014; Orsini et al. 2014). The results of the study by Ghane et al. (2013) stated that Comamonas sp. HM_AF12 obtained from industrial waste reduces the heavy metal chromium (Cr) by $80 \%$. This was conducted over the original value 
for one hour, assuming that the high resistance and the great potential act as a bioremediation agent. Similarly, Siunova et al. (2009) stated that Comamonas sp. BS501, Comamonas sp. HM_AF12 and C. testosteroni TDKW are resistant to cobalt and manganese, heavy metals such as $\mathrm{Cu}$ and $\mathrm{C}$, and $\mathrm{Cr}, \mathrm{Hg}, \mathrm{Zn}$, and $\mathrm{Cu}$ respectively.

In this study, the profile of bacteria from $\mathrm{Pb}$-reduction Tempe Lake in South Sulawesi as a candidate for a bioremediation agent was identified. The use of microorganisms, such as bacteria, can be isolated from $\mathrm{Pb}$ contaminated waters, and the process is called bioremediation. By the reduction test, the contained $\mathrm{Pb}$ concentrations and its reducing ability are showed by using the bacterial bioremediation agent isolated. Also, indigenous bacteria incorporate biochemical and molecular processes on the ground that pollutants are not harmful to the environment. However, this study did not cover how the metabolism of the bacterial body reduces metals and survives in polluted areas following the molecular basis.

In conclusion, four isolates were obtained from the Tempe Lake water. However, among the four strains, only one isolate had the highest potency for reducing $\mathrm{Pb}$ (Isolate D) with the degradation of $53.35 \%$. The most potent bacterial species based on the 16s rDNA gene analysis had a $99 \%$ similarity to $C$. testosteroni strain S-2 of the Neighbor-Joining phylogenetic tree with 1000 bootstraps. Therefore, it is reasonable to conclude that $C$. testosteroni strain $S$-2 in Tempe Lake reduces heavy metals lead as a bioremediation agent. However, further investigations on a molecular basis should be conducted to empirically demonstrate the $C$. testosteroni strain $\mathrm{S}-2$ reduction of the lead.

\section{ACKNOWLEDGEMENTS}

The authors are sincerely grateful to the institutions that contributed to this study. LPDP supports this research: PRJ-6586/LPDP.3/2016. The authors are further grateful to the RISTEKDIKTI, Republic of Indonesia as a scholarship provider ministry of finance.

\section{REFERENCES}

Aisyah S, Nomosatryo S. 2016. Spatial and temporal distribution of nutrients in Lake Tempe, South Sulawesi. Oseanologi dan Limnologi, 1 (2): 31-45. http://jurnal-oldi.or.id/index.php/oldi/article/view/19/30. [Indonesian]

Ali H, Khan E, Ilahi I. 2019. Environmental chemistry and ecotoxicology of hazardous heavy metals : Environmental persistence, toxicity, and bioaccumulation. J Chem. DOI: 10.1155/2019/6730305.

Anyanwu BO, Ezejiofor AN, Igweze N, Orisakwe OE. 2018. Heavy metal mixture exposure and effects in developing nations: An update. Toxics 6 (65): 1-32. DOI: 10.3390/toxics6040065.

Batta N, Subudhi S, Lal B, Devi A. 2013. Isolation of a lead tolerant novel bacterial species, Achromobacter sp. TL-3: Assessment of bioflocculant activity. Indian J Exp Biol 51 (1): 1004-1011.

Bello AO, Tawabini BS, Khalil AB, Boland CR. 2018. Phytoremediation of cadmium-, lead- and nickel-contaminated water by Phragmites australis in hydroponic systems. Ecol Eng 120: 126-133. DOI: 10.1016/j.ecoleng.2018.05.035.

Bennisse R, Labat M, ElAsli A, Brhada F, Chandad F, Lorquin J, Liegbott PP, Hibti M, Qatibi AI. 2004. Rhizosphere bacterial populations of metallophyte plants in heavy metal-contaminated soils from mining areas in semiarid climate. World J Microbiol Biotechnol 20 (7): 759766. DOI: $10.1007 / \mathrm{s} 11274-004-5812-2$.

Black R, Sartaj M, Mohammadian A, Qiblawey HAM. 2014. Biosorption of $\mathrm{Pb}$ and $\mathrm{Cu}$ using fixed and suspended bacteria. Biochem Pharmacol 2 (3): 1663-1671. DOI: 10.1016/j.jece.2014.05.023.

Carolin CF, Kumar PS, Saravanan A, Joshiba GJ, Naushad M. 2017. Efficient techniques for the removal of toxic heavy metals from aquatic environment: A review. J Environ Chem Eng 5 (3): 27822799. DOI: $10.1016 /$ j.jece.2017.05.029.

Chen Z, Pan X, Chen H, Lin Z, Guan X. 2015. Investigation of lead(II) uptake by Bacillus thuringiensis 016. World J Microbiol Biotechnol 31 (11): 1729-1736. DOI: 10.1007/s11274-015-1923-1.

Cheyne CAL, Thibodeau AM, Slater GF, Bergquist BA. 2017. Lead isotopes as particulate contaminant tracers and chronostratigraphic markers in lake sediments in northeastern North America. Chem Geol 477 (20): 47-57. DOI: 10.1016/j.chemgeo.2017.11.043.

Deepa, Raveen, Venkatesan, Arivoli, Samuel. 2016. Seasonal variations of physicochemical parameters of Korattur lake, Chennai, Tamil Nadu, India. Intl J Chem Stud 4 (43): 116-123.

Dey U, Chatterjee S, Mondal NK. 2016. Isolation and characterization of arsenic-resistant bacteria and possible application in bioremediation. Biotechnol Rep 10: 1-7. DOI: 10.1016/j.btre.2016.02.002.

Dixit R, Malaviya D, Pandiyan K, Singh UB, Sahu A, Shukla R, Singh BP, Rai JP, Sharma PK, Lade H, Paul D. 2015. Bioremediation of heavy metals from soil and aquatic environment: An overview of principles and criteria of fundamental processes. Sustainability 7: 2189-2212. DOI: 10.3390/su7022189.

Gafur NA, Sakakibara M, Sano S, Sera K. 2018. A case study of heavy metal pollution in water of bone river by artisanal small-scale gold mine. Water 10 (1507): 1-10. DOI: 10.3390/w10111507.

Garcha S, Verma N, Brar SK. 2016. Isolation, characterization, and identification of microorganisms from unorganized dairy sector wastewater and sludge samples and evaluation of their biodegradability. Water Resour Ind 16: 19-28. DOI: 10.1016/j.wri.2016.10.002.

Ghane M, Tabandeh F, Bandehpour M, Ghane M. 2013. Isolation and characterization of a heavy metal resistant Comamonas sp . from industrial effluents. Iranian J Sci Technol 37 (A2): 173-179.

Gohil N, Singh V, Ramı R. 2019. Recent advances, challenges, and opportunities in bioremediation of hazardous materials. In: Phytomanagement of Polluted Sites. Elsevier, Nederlands. DOI: 10.1016/B978-0-12-813912-7.00021-1.

Haerunnisa H, Budimawan B, Alam Ali S, Burhanuddin AI. 2015. Management model of sustainability fisheries at Lake Tempe, South Sulawesi, Indonesian. Int J Sci Res 4 (5): 2319-7064.

Igiri BE, Okoduwa SIR, Idoko GO, Akabuogu EP, Adeyi AO, Ejiogu I. K. 2018. Toxicity and bioremediation of heavy metals contaminated ecosystem from tannery wastewater : A review. J Toxicol 2018. DOI: $10.1155 / 2018 / 2568038$

Irawati W, Ompusunggu NP, Susilowati DN, Yuwono T. 2019. Molecular and physiological characterization of indigenous copper-resistant bacteria from Cikapundung River, West Java, Indonesia. Biodiversitas 20 (2): 344-349. DOI: 10.13057/biodiv/d200206.

Jan AT, Azam M, Siddiqui K, Ali A, Choi I. 2015. Heavy metals and human health: Mechanistic insight into toxicity and counter defense system of antioxidants. Int J Mol Sci 16 (12): 29592-29630. DOI: 10.3390/ijms161226183.

Jiang Y, Ye Y, Guo X. 2019. Spatiotemporal variation of soil heavy metals in farmland influenced by human activities in the Poyang Lake region, China. Catena 176: 279-288. DOI: 10.1016/j.catena.2019.01.028.

Junior R, Aka N, Babalola OO. 2017. Identification and characterization of Cr- , Cd- , and Ni-tolerant bacteria isolated from mine tailings. Bioremed J 21 (1): 1-19. DOI: 10.1080/10889868.2017.1282933.

Kang C, Ji S, Shin Y, Han S, Nam I. 2015. Bioremediation of lead by ureolytic bacteria isolated from soil at abandoned metal mines in South Korea. Ecol Eng 74: 402-07. DOI: 10.1016/j.ecoleng.2014.10.009.

Khazaal SH, Al-Azawi KF, Eassa HA, Khasraghi AH, Alfatlawi WR, AlGebori AM. 2019. Study the level of some heavy metals in water of Lake Habbaniyah in Al-Anbar-Iraq. Energy Procedia 157: 68-74. DOI: 10.1016/j.egypro.2018.11.165.

Krieg NR, Holt JG. 1984. Bergy's manual of systematic bacteriology vol 1. The Williams and Wilkins Co., Baltimore. 
Kumar JN, Soni H, Kumar RN, Bhatt I. 2008. Macrophytes in phytoremediation of heavy metal contaminated water and sediments in Pariyej Community Reserve, Gujarat, India. Turk J Fish Aquat Sci 8 (2): 193-200

Li Y, Zhou S, Zhu Q, Li B, Wang J, Wang C, Chen L, Wu S. 2018. Onecentury sedimentary record of heavy metal pollution in western Taihu Lake, China. Environ Pollut 240: 709-716. DOI: 10.1016/j.envpol.2018.05.006.

Lu X, Kruatrachue M, Pokethitiyook P. 2004. Removal of cadmium and zinc by water hyacinth, Eichhornia crassipes Xiaomei. ScienceAsia 30 (1): 93-103. DOI: 10.2306/scienceasia1513-1874.2004.30.093.

Mary J, Karthik C, Ganesh R, Kumar SS, Prabakar D, Kadirvelu K, Pugazhendhi A. 2018. Biological approaches to tackle heavy metal pollution: A survey of literature. J Environ Manag 217: 56-70. DOI: 10.1016/j.jenvman.2018.03.077.

Marzan LW, Hossain M, Mina SA, Akter Y, Chowdhury AMMA. 2017. Isolation and biochemical characterization of heavy-metal resistant bacteria from tannery effluent in Chittagong city, Bangladesh: Bioremediation viewpoint. Egypt J Aquat Res 43 (1): 65-74. DOI: 10.1016/j.ejar.2016.11.002

Naik MM, Dubey SK. 2013. Lead resistance mechanisms, their applications in lead bioremediation and biomonitoring. Ecotoxicol Environ Saf 98 (1): 1-7. DOI: 10.1016/j.ecoenv.2013.09.039.

Naik MM, Khanolkar D, Dubey SK. 2013. Lead-resistant Providencia alcalifaciens strain 2EA bioprecipitates $\mathrm{Pb}+2$ as lead phosphate. Lett Appl Microbiol 56 (2): 99-104. DOI: 10.1111/lam.12026.

Orsini J, Tam E, Hauser N, Rajayer S, Report C. 2014. Polymicrobial bacteremia involving Comamonas testosteroni Jose. Case Rep Med 3 (1): $15-18$.

Pambudiono A, Suarsini E, Amin M, Pambudiono A, Suarsini E, Amin M, Biologi P, Magister P, Malang UN, Biologi J, Malang UN. 2016. Isolasi dna genom bakteri potensial pengkelat logam berat kadmium dari limbah cair penepungan agar. Prosiding SNPBS (Seminar Nasional Pendidikan Biologi dan Saintek) Ke-1, Universitas Muhammadiyah Surakarta, 2016: 103-107. [Indonesian]

Pan X, Chen Z, Li L, Rao W, Xu Z, Guan X. 2017. Microbial strategy for potential lead remediation: a review study. World J Microbiology Biotechnol 33 (2): 1-7. DOI: 10.1007/s11274-017-2211-z.

Pance R, Sarrafah A, Manurung H, Harahap TN, Retnowati I, Rachmiati S, Nasution, Rustadi WC. 2014. Gerakan Penyelamatan Danau Tempe. Kementerian Lingkungan Hidup, Jakarta. [Indonesian]

Parmar TK, Rawtani D, Agrawal YK. 2016. Bioindicators: the natural indicator of environmental pollution. Front Life Sci 9 (2): 110-118. DOI: $10.1080 / 21553769.2016 .1162753$.

Rijal M, Amin M, Rochman F, Suarsini E, Alim NN. 2015. The quality of physical and chemical the waters of the areas Ambon. Intl $\mathrm{J}$ Multidisciplinary Res Dev 2 (4): 87-92.

Risna A, Andriani I, Ashraf A, Omar SBA, Sari DK. 2020. Histopathological study of kidney and meat of Bungo Fish
(Glossogobius $\mathrm{sp}$ ) contaminated by Lead Metal $(\mathrm{Pb})$ in Lake Tempe, Wajo Regency. IOP Conf Ser: Earth Environ Sci 48 (1). DOI: 10.1088/1755-1315/486/1/012011.

Sa' diyah W, Suarsini E, Ibrohim I. 2017. Effectiveness of indigenous lead $(\mathrm{Pb})$ reducing bacteria consortia of wastewater treatment in agar flour industry. J Exp Life Sci 6 (1): 34-37. DOI: 10.21776/UB.JELS.2016.006.01.09.

Sanjay MS, Sudarsanam D, Raj GA, Baskar K. 2018. Isolation and Identification of chromium reducing bacteria from tannery effluent. J King Saud Univ Sci 32 (1): 265-271. DOI: 10.1016/j.jksus.2018.05.001.

Sharma B, Shukla P. 2021. Lead bioaccumulation mediated by Bacillus cereus BPS-9 from an industrial waste contaminated site encoding heavy metal resistant genes and their transporters. J Hazard Mater 401: 123285. DOI: 10.1016/j.jhazmat.2020.123285.

Siunova TV, Siunov AV, Kochetkov VV, Boronin AM. 2009. The cnrlike operon in strain Comamonas sp. encoding resistance to cobalt and nickel. Russian J Genet 45 (3): 336-341. DOI: 10.1134/S1022795409030053.

Sowmya M, Hatha AAM. 2017. Cadmium and lead tolerance mechanisms in bacteria and the role of halotolerant and moderately halophilic bacteria in their remediation (Issue January). Taylor \& Francis, London. DOI: 10.1201/9781315153353-40.

Talukdar D, Sharma R, Jaglan S, Vats R, Kumar R, Mahnashi MH, Umar A. 2020. Identification and characterization of cadmium resistant fungus isolated from contaminated site and its potential for bioremediation. Environ Technol Innov 17: 100604. DOI: 10.1016/j.eti.2020.100604.

Tamura K, Stecher G, Peterson D, Filipski A, Kumar S. 2013. MEGA6: Molecular evolutionary genetics analysis version 6.0. Mol Biol Evol 30 (12): 2725-2729. DOI: 10.1093/molbev/mst197.

Theiman W, Palladino MA. 2013. Introduction to Biotechnology. 3rd ed. Pearson Education, UK.

Wang H, Zhang H, Cai G. 2011. An application of phytoremediation to river pollution remediation. Procedia Environ Sci 10 (PART C): 1904-1907. DOI: 10.1016/j.proenv.2011.09.298.

Yang T, Chen M, Wang J. 2015. Genetic and chemical modification of cells for selective separation and analysis of heavy metals of biological or environmental significance. Trends Anal Chem 66: 90 102. DOI: $10.1016 /$ j.trac.2014.11.016

Yani A, Amin M, Rohman F, Suarsini E, Haerunnisa. 2019. Water quality and pollution index of Lake Tempe in South Sulawesi Indonesia. Pollut Res 38 (3): 54-60.

Zheng S, Su J, Wang L, Yao R, Wang D, Deng Y, Wang R, Wang G. 2014. Selenite reduction by the obligate aerobic bacterium Comamonas testosteroni $\mathrm{S} 44$ isolated from a metal-contaminated soil. BMC Microbiol 14 (204): 1-13. DOI: 10.1186/s12866-014-0204-8. 